Review

\title{
Mathematical and Experimental Science Education from the School Garden: A Review of the Literature and Recommendations for Practice
}

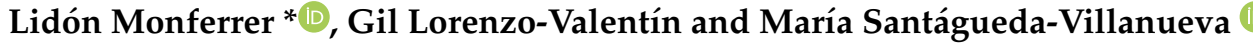

check for

updates

Citation: Monferrer, L

Lorenzo-Valentín, G.

Santágueda-Villanueva, M. Mathematical and Experimental Science Education from the School Garden: A Review of the Literature and Recommendations for Practice. Educ. Sci. 2022, 12, 47. https:// doi.org/10.3390/educsci12010047

Academic Editor: Marcia

Eugenio-Gozalbo

Received: 15 December 2021

Accepted: 10 January 2022

Published: 14 January 2022

Publisher's Note: MDPI stays neutral with regard to jurisdictional claims in published maps and institutional affiliations.

Copyright: (C) 2022 by the authors. Licensee MDPI, Basel, Switzerland. This article is an open access article distributed under the terms and conditions of the Creative Commons Attribution (CC BY) license (https:// creativecommons.org/licenses/by/ $4.0 /)$.
Department of Education and Specific Didactics, Faculty of Humanities and Social Sciences, University Jaume I of Castellón, 12071 Castellón de la Plana, Spain; gil.lorenzo@uji.es (G.L.-V.); santague@uji.es (M.S.-V.)

* Correspondence: lidon.monferrer@uji.es

\begin{abstract}
The much-needed interest in promoting a healthy lifestyle among school-age students has found a context for development: school gardens. There are numerous studies where using gardens as a teaching-learning context also improves students' performance in the experimental sciences. In this study, we proposed another interest that sets it apart and adds motivation: combining curricular mathematics with experimental science content in this context. The search for possible studies in the scientific literature has gave rise to the review presented herein. From this review, we obtained 21 studies, from which we extracted a series of categories: whether research was undertaken and with which tools; which curricular contents were covered and the impact produced; the ages of the participants and duration of the project; and, finally, whether the garden was cultivated. The main conclusion of this search was the lack of a clear line of research linking school gardens, the experimental sciences, and mathematics, in addition to the scant presence of studies framed in this context. For that reason, we send a call to action to the scientific community encouraging the interdisciplinarity of the two aforementioned subjects within the context of school gardens.
\end{abstract}

Keywords: experimental sciences; environmental education; mathematics; interdisciplinarity; research on scientific literature; bibliographical review

\section{Introduction}

Since the late 20th and early 21st centuries, society has shown more awareness of nutrition and health. Some of this concern is due to the fact that rates of obesity and overweightness in childhood and adolescence in the USA are situated at 34\% [1,2] and, to a lesser extent, at $26 \%$ in Spain [3]. Added to this reality is the circumstance that younger people are increasingly adopting a sedentary and inactive lifestyle, disconnected from the natural world $[4,5]$.

In relation to nutrition, natural surroundings such as school gardens can be used to encourage healthy eating habits [6,7]. In their study, Berezowitz et al. [8] observed a favourable impact on fruit and vegetable consumption at schools where students worked in a school garden. The gardens and kitchens at some schools were considered living, interactive classrooms where working on food education, fresh foods, and a food-based curriculum offered numerous educational connections [9].

In relation to a sedentary lifestyle, disconnected from nature, Louv [4] coined the term nature deficit disorder after researching the negative effects on the emotional and physical health of children and adults when away from natural surroundings. This author co-founded the Children and Nature Network to respond to the need for exposure to outdoor spaces where children could play and experience nature. Along these lines, the environmental education-based schools like the natural preschool and forest kindergartens, which first appeared in the USA and Europe in the second half of the 20th century, are growing in number in several countries, including Scandinavia and Switzerland [10]. In 
this trend of naturalising learning spaces, the school garden provides a direct and regular experience of nature in urban settings, enabling the development of a positive relationship and of attitudes of care and respect for nature [11].

Creating a school garden leads to garden-based learning, which, according to Desmond et al. [12], encompasses 'programmes, activities and projects in which the garden is the foundation for integrated learning, in and across disciplines, through active, engaging, real-world experiences' [12] (p. 7). Eugenio-Gozalbo et al. [13] translated the English term, garden, as 'huerto'. In teaching materials in Spanish, it is usually translated as 'jardín', which also means 'huerto', the place where vegetables are grown. In the UK, the term 'jardín' is associated with growing species of trees, bushes, and ornamental herbaceous borders (mainly flowering plants) often near a pond (with associated fauna). The term 'huerto', however, is an area dedicated to growing edible vegetables (including Solanaceae, Cucurbitaceae, and Cruciferae), where composters and vermicomposters are present.

According to Williams's review [9], in Garden-based learning, the local particularities of gardens offer a broad diversity of designs and differentiating characteristics. These nuances are down to different types of climate, growing season, available resources, and intervention of elements outside the school, among others. This wide range of possible combinations has meant that this type of learning lacks a more uniform and explicitly unifying pedagogical theory. We can say that garden-based learning rests on the principles of various educational theories, such as experiential [14-16], environmental [17-19], holistic [18,19], outdoor [20-22], and place-based education [23-25]. This wealth of theories and lack of concrete detail for garden-based learning have given rise to the theorisation of seven pedagogical principles: location-based food growing, encouraging curiosity and amazement, discovering rhythm and scale, valuing biocultural diversity and practical experience, promoting interconnection, and awakening the senses [25].

It is important to emphasise that the use of school gardens benefits the school community, which becomes more creative, more pacific, more physically active, and more aware of healthy eating [26]. We also highlight the cognitive benefits for children. Several studies show improvements in academic results related to the curriculum/specific subjects like the sciences, arts, language, mathematics, and social studies, among others. After a review of the impact of garden use on academic results, Williams and Dixon [11] found that garden-based learning led to better academic performance, mainly in scientific subjects.

These positive effects in academic performance are related to studies that show that outdoor environments can enhance contextualisation in lessons in experimental science in primary education without affecting pupils' performance [27-29]. In mathematics, experiences outside the classroom help children to connect the subject with the world around them [30]. The possibility of teaching this subject outside the classroom offers a different environment that enables teachers to contextualise certain concepts [31]. These situations developed outside the classroom are infinite and different from each other. They can therefore be described as a process of renewal. Studies in outdoor learning have shown benefits for all the educational community [21]. Numerous studies show that learning environments could positively influence knowledge [27], attitude [32,33], interest, or motivation to learn [34].

If we revisit the definition of garden-based learning, the description of 'learning integrated in and across disciplines' enables us to use the school garden to improve academic performance in mathematics and the experimental sciences from an interdisciplinary approach. The term interdisciplinarity refers to the relationship between two or more disciplines that seek a greater understanding of reality to enhance the contributions of each of the disciplines involved. Motta [35] (p. 2) defined it as a dialogue, a reciprocal relationship, an interpenetration between disciplines around the same object, situation, or phenomenon. This synergy between the experimental sciences and mathematics aims to create an atmosphere of study of meanings and situations that are significant for pupils. 
One of the strategies used by teachers during the mathematics learning process is to bring pupils closer to a reality in which the mathematical structures being studied will appear. To that end, one possibility is to turn to other sciences that use mathematics [36]. For several years, the international mathematics community has been interested in broad sectors of society learning the benefit of a culture that integrates experimental science and mathematics [36]. This integration of both areas of knowledge could facilitate an understanding of mathematics and the experimental sciences by using the interdisciplinarity between them as a methodological strategy in a school-garden context.

Despite the numerous reviews in recent years about the benefits of garden-based learning outlined above, we believe in the need to review the academic effects on mathematics and the experimental sciences when the approach is interdisciplinary. Considering the above, the objective of this work was to discover and analyse studies on garden-based learning in the experimental sciences and mathematics, in pupils between the ages of three and twelve years, both in Spain and in other countries, based on a systematic review of documents published in databases of scientific interest in education.

\section{Materials and Methods}

\subsection{Search Strategies}

This descriptive review was undertaken in the main databases with an international scientific acknowledgement in education: Web of Science (WoS), Scopus-Elsevier (Scopus), and Education Resources Information Center (ERIC) [37]. The review was quantitative (number of works found using keywords) and qualitative (a more detailed analysis of the contributions of each study in our objectives). In the first quarter of 2020, we searched publications containing subject matter relating to mathematics and the school garden in school stages known in Spain as early years (0-6 years) and primary education (7-12 years). Although we used the Spanish education system as our reference, our objective of international analysis led us to limit this information to years, since in other educational systems the stages cover different time periods. Deciding on the keywords led us to consider several, which we linked to Boolean operators with 'and'. They were garden and math, for the part concerning school garden and mathematics, and kinder, primary, and elementary for the part concerning the educational stages considered. We made all possible combinations to achieve a comprehensive sweep.

\subsection{Inclusion and Exclusion Criteria}

Inclusion and exclusion criteria made it possible to reject information that does not coincide with the aim of our work. The languages chosen for the studies included in the search were Spanish and English. We also considered shortening the interval or range of years (the last 20 years) for which to search. However, we eventually discarded this idea because practically all the publications found were located within the time range and, again, we did not want to reject any that might be important for this purpose. The documents sought were books, book chapters, and articles. These details were thus entered into the filter of the corresponding browsers. Finally, our intention was not to consider texts that had nothing to do with educational subjects. However, it was not necessary because the etymology of the keywords chosen was always linked to education.

In the screening phase (Figure 1), we used exclusion criteria such as age range. Some articles were focused only on students over 12 years old and we were interested in primary education. Another criterion was that the contents of mathematics and science should appear in the article. Some studies focus on environmental attitudes but not on the study of the contents of mathematics and science, so we excluded these publications. Finally, other publications were social proposals that we were not interested in for this study. 


\section{IDENTIFICATION PHASE}
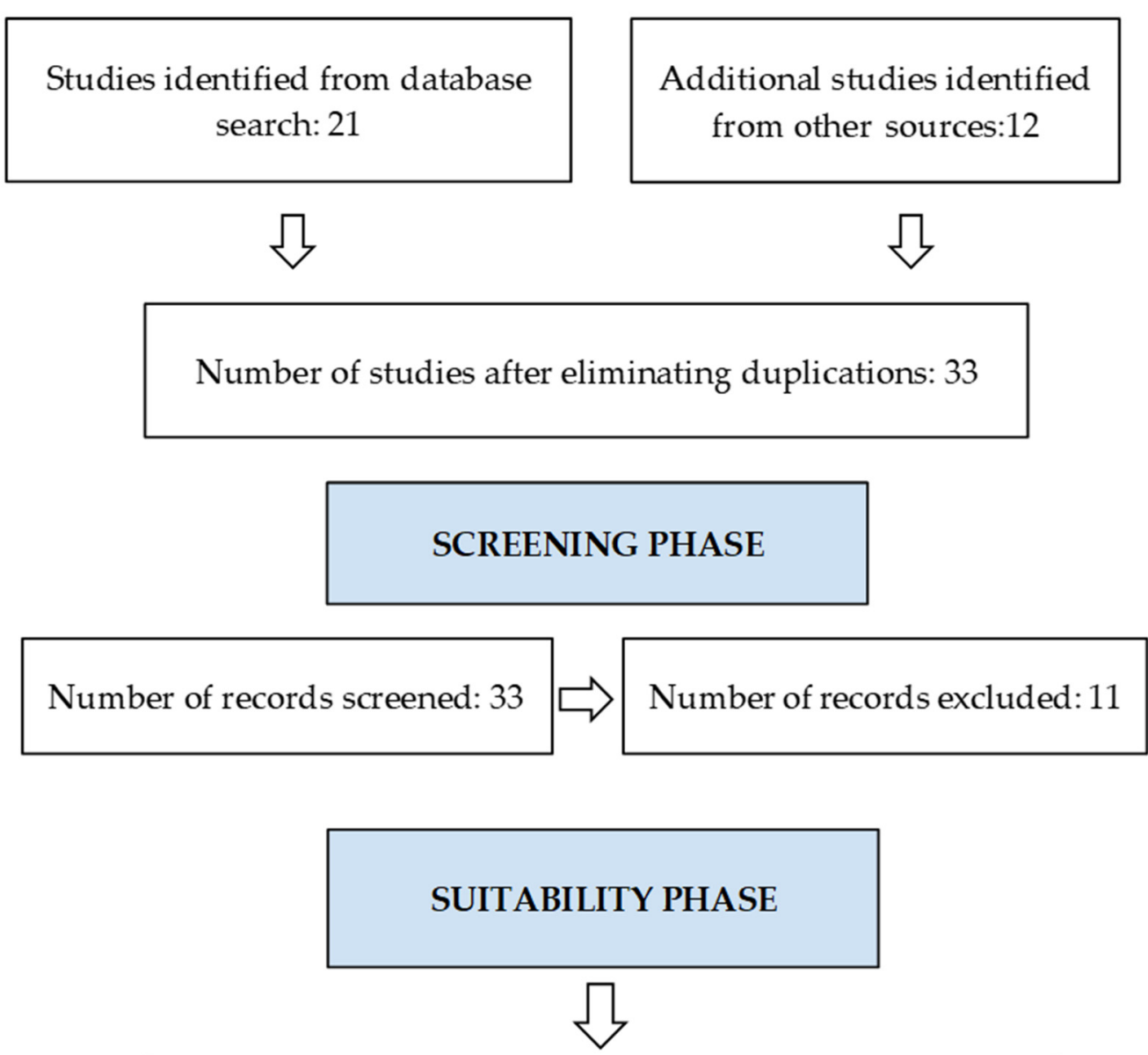

Number of full-text articles evaluated for eligibility: 22

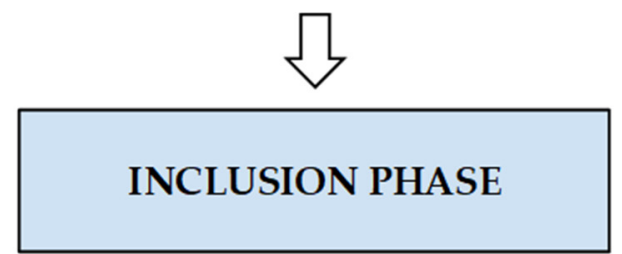

Number of studies included in the qualitative synthesis: 22

Figure 1. Search flow. Adapted from Moher et al. [37]. 


\subsection{Review Procedure}

Initially, we carried out independent searches in the three databases considered and all obtained the same results in each one. We named this initial phase of the review as the identification of texts for consideration, the number obtained being 76 . We reviewed the bibliography considered in the chosen articles (which is known as the snowball method) and extended it to encompass 12 new publications for review. Of this number (88), once the duplicates were eliminated, the number of studies to be evaluated was 33 . In the following phase, which we call screening, in which the exclusion criteria were applied, the number was reduced to 21 . Next, in the suitability phase, we analysed the 21 studies in detail. None were discarded since all met the objectives of our review. Therefore, in the final inclusion phase, 21 articles were considered (Figure 1).

\subsection{Categories Analysed}

Analysis of the 21 studies in the inclusion phase was organised according to the following categories: research method, research instruments used, curricular content (special attention if content was from mathematics or the experimental sciences), age of participants, impact in educational and social spheres, duration of the project, if the study included whether the school garden had been cultivated or not, and if the production had been used. Table 1 provides a summary of these categories, which are explained in Sections 3.1-3.7. 
Table 1. Descriptive categories of publications on education in mathematics and the experimental sciences in the school garden.

\begin{tabular}{|c|c|c|c|c|c|c|c|c|c|}
\hline Authors & $\begin{array}{c}\text { Experience } \\
\text { (0) or } \\
\text { Research (1) }\end{array}$ & $\begin{array}{l}\text { Research } \\
\text { Method }\end{array}$ & Instrument & $\begin{array}{l}\text { Curricular } \\
\text { Content }\end{array}$ & Ages (Years) & Impact & $\begin{array}{l}\text { Project } \\
\text { Duration } \\
\text { (Months) }\end{array}$ & Agriculture & $\begin{array}{l}\text { Use of } \\
\text { Harvest }\end{array}$ \\
\hline Hinnant [38] & 0 & & & $\begin{array}{l}\text { Mathematics } \\
\text { (M) }\end{array}$ & $6-7$ & None & None specified & No & No \\
\hline Meyer et al. [39] & 0 & & & $\begin{array}{l}\text { Experimental } \\
\text { sciences (ES) }\end{array}$ & $3-12$ & Improves interest in ES & 3 & Yes & No \\
\hline Waliczck et al. [40] & 1 & Qualitative & $\begin{array}{c}\text { Interviews } \\
\text { analysed with } \\
\text { QSR NUD*IST }\end{array}$ & $\mathrm{M}$ and ES & $8-10$ & $\begin{array}{l}\text { Improves attitudes to } \mathrm{M} \\
\text { and ES }\end{array}$ & None specified & Yes & No \\
\hline Klemmer et al. [41] & 1 & Quantitative & TEKS $^{1}$ & ES & $8-10$ & $\begin{array}{c}\text { Improves experimental } \\
\text { environment }\end{array}$ & None specified & Yes & $\begin{array}{c}\text { None } \\
\text { specified }\end{array}$ \\
\hline Pigg et al. [42] & 1 & Quantitative & $\begin{array}{c}\text { TAKS }^{2} \\
\text { questionnaire is } \\
\text { analysed with } \mathrm{R}\end{array}$ & $\mathrm{M}$ and $\mathrm{ES}$ & $8-11$ & $\begin{array}{l}\text { In 3rd and } 4 \text { th years } \\
\text { everything improves } \\
\text { except M. In 5th year } \\
\text { complete with a } \\
\text { traditional class }\end{array}$ & 12 & No & No \\
\hline $\begin{array}{l}\text { Starbuck and } \\
\text { Olthof [44] }\end{array}$ & 0 & & & $\begin{array}{c}\text { Fine and gross } \\
\text { motor skills, ES, } \\
\text { Language, M }\end{array}$ & $3-6$ & $\begin{array}{l}\text { Improvement in } \\
\text { educational community }\end{array}$ & 6 & Yes & Yes \\
\hline Boynton [45] & 1 & Qualitative & Open interviews & M & $3-12$ & $\begin{array}{l}\text { Working in the garden } \\
\text { improves another subject }\end{array}$ & 3 & Yes & No \\
\hline Jaeschke et al. [46] & 1 & Quantitative & $\begin{array}{l}\text { Questionnaire } \\
\text { devised }\end{array}$ & ES & $3-12$ & $\begin{array}{l}\text { Improves pupils' } \\
\text { perceptions of nutrition }\end{array}$ & 6 & No & No \\
\hline Taylor [47] & 0 & & & M & $5-12$ & Improvement in $\mathrm{M}$ & None specified & No & No \\
\hline $\begin{array}{l}\text { Fisher-Maltese and } \\
\text { Carley [48] }\end{array}$ & 1 & Mixed & $\begin{array}{l}\text { Questionnaires, } \\
\text { interviews }\end{array}$ & ES & $8-9$ & Improvement in ES & None specified & No & No \\
\hline
\end{tabular}


Table 1. Cont.

\begin{tabular}{|c|c|c|c|c|c|c|c|c|c|}
\hline Authors & $\begin{array}{l}\text { Experience } \\
\text { (0) or } \\
\text { Research (1) }\end{array}$ & $\begin{array}{l}\text { Research } \\
\text { Method }\end{array}$ & Instrument & $\begin{array}{l}\text { Curricular } \\
\text { Content }\end{array}$ & Ages (Years) & Impact & $\begin{array}{l}\text { Project } \\
\text { Duration } \\
\text { (Months) }\end{array}$ & Agriculture & $\begin{array}{c}\text { Use of } \\
\text { Harvest }\end{array}$ \\
\hline $\begin{array}{l}\text { Williams and } \\
\text { Dixon [11] }\end{array}$ & 1 & Quantitative & Systematic review & None specified & $3-16$ & $\begin{array}{l}\text { Improvement in } \mathrm{M} \text { and } \\
\text { ES }\end{array}$ & 240 & No & No \\
\hline Selmer et al. [49] & 0 & & & $\begin{array}{c}\text { M, ES and } \\
\text { engineering }\end{array}$ & $6-12$ & $\begin{array}{c}\text { Improve statistical } \\
\text { literacy }\end{array}$ & None specified & Yes & Yes \\
\hline $\begin{array}{l}\text { Akoumianak } \\
\text { et al. [50] }\end{array}$ & 1 & Mixed & $\begin{array}{l}\text { Questionnaire } \\
\text { with open and } \\
\text { closed questions } \\
\text { SPSS analysis }\end{array}$ & $M$ and ES & $10-12$ & $\begin{array}{l}\text { Improves } \mathrm{M} \text { and } \\
\text { environmental } \\
\text { perspective }\end{array}$ & None specified & Yes & No \\
\hline Brkich et al. [51] & 0 & & & $\mathrm{M}$ and ES & $8-11$ & $\begin{array}{l}\text { Improves learning and } \\
\text { attitudes to STEM }\end{array}$ & None specified & No & No \\
\hline $\begin{array}{l}\text { Camasso and } \\
\text { Jagannathan [52] }\end{array}$ & 1 & Quantitative & $\begin{array}{l}\text { Pre- and post-test } \\
\text { comparison }\end{array}$ & ES & $6-12$ & Improves access to ES & 48 & Yes & No \\
\hline Davis [53] & 1 & Mixed & $\begin{array}{l}\text { Interviews and } \\
\text { IoT }^{4} \\
\text { questionnaire }\end{array}$ & $\begin{array}{l}\text { M, technology } \\
\text { and ES }\end{array}$ & $8-9$ & $\begin{array}{l}\text { Develops creation and } \\
\text { creativity }\end{array}$ & 4 & $\begin{array}{l}\text { Germination in } \\
\text { the classroom }\end{array}$ & No \\
\hline Ürey et al. [54] & 1 & Qualitative & Open interviews & $\begin{array}{l}\text { Interdisciplinary } \\
\text { but not specific }\end{array}$ & $\begin{array}{l}\text { Does not } \\
\text { specify }\end{array}$ & $\begin{array}{l}\text { Improves attitudes to the } \\
\text { environment }\end{array}$ & 4 & No & No \\
\hline Jagger [55] & 1 & Qualitative & Open interviews & $M$ and ES & $8-12$ & $\begin{array}{c}\text { Improves in } \mathrm{M} \text { when } \\
\text { undertaken } \\
\text { experimentally }\end{array}$ & None specified & Yes & No \\
\hline Savi Ruijs et al. [56] & 1 & Quantitative & $\begin{array}{c}\text { A/B test } \\
\mathrm{R} \text { (R Core Team) } \\
\text { and RStudio }\end{array}$ & $\mathrm{M}$ and ES & $4-12$ & Improvement in $\mathrm{M}$ & 3 & No & No \\
\hline Khan et al. [57] & 1 & Mixed & Questionnaires & None specified & $8-11$ & $\begin{array}{l}\text { Improves academic } \\
\text { performance }\end{array}$ & 7 & No & No \\
\hline
\end{tabular}




\section{Results}

Table 1 shows the results of the analysis of the studies derived from the inclusion phase, which consists of the categories outlined in Section 2.4. Above Table 1, and within this Section 3, these categories are explained in detail.

\subsection{Research Methods}

Among the research studies considered, five were qualitative, for which interviews or questionnaires had been performed with questions for members of the educational community $[40,43,45,54,55]$. We detected six quantitative $[48,50,53,57]$ and four mixed-method studies $[48,50,53,57]$. No less valuable were six other studies that recount experiences, shown in Table $1[38,39,44,47,49,51]$, which can be replicated.

\subsection{Research Instruments}

Table 2 provides a summary of the research instruments used in the documents analysed. The most used instrument in nine studies is the questionnaire. This is indicated in most studies, specifically in six, but there is no consensus on the questions asked. Each study uses several questions, but none of them link mathematics with the experimental sciences in the garden. The second research instrument most used is the interview, which appeared in seven studies. Finally, two studies analyse productions carried out in the school environment in analogue format: graphs, written answers, and so forth.

Table 2. Research instruments used.

\begin{tabular}{lcc}
\hline \multicolumn{2}{l}{ Instruments } & Reference \\
\hline \multicolumn{2}{l}{ Interviews } & {$[40,43,45,48,53-55]$} \\
\hline \multicolumn{2}{c}{ Classwork } & {$[43]$} \\
\hline \multirow{2}{*}{ Unspecified questionnaires } & Questions & {$[50]$} \\
& Test A/B & {$[48,52,57]$} \\
& TEKS & {$[56]$} \\
& TAKS & {$[41]$} \\
& IoT & {$[42]$} \\
& Own questionnaire & {$[53]$} \\
& &
\end{tabular}

Not all studies specify which computer tools they use to analyse the instruments: [21,42] use R Studio; [40] used QSR NUD*IST and [50] opted for SPSS.

The study presented in [11] was a bibliographical search. Therefore, the instrument it used was the EBSCO database and the results were analysed with the Evaluation program or Evaluation research.

\subsection{Curricular Content Followed}

We analysed the curricular content of the experimental sciences and mathematics. Table 3 lists the content related to the experimental sciences: $14.28 \%$ mainly involve working with plants, followed by $9.5 \%$ that deal with nutrition and health (studies $[39,43]$ ) and sensory experiences (studies [52,55]). Other studies that address diverse content, including animal study (studies [46,51]), represent 9.5\%. Only 4.7\% explore aspects of leadership and scientific environment in horticulture ([41]). The same percentage of studies use sensor technology ([53]). Significantly, 33\% of the studies do not specify the content followed in the experimental sciences. 
Table 3. Curricular content of the experimental sciences.

\begin{tabular}{cc}
\hline Curricular Content & Reference \\
\hline Unspecified & {$[11,40,42,44,48,49,56]$} \\
\hline Plants & {$[50,53,55]$} \\
\hline $\begin{array}{c}\text { Amphibians, turtles, and serpents; insects and diseases; fruits and } \\
\text { dried fruits, vegetables and herbs. }\end{array}$ & {$[51]$} \\
\hline Focus on the natural world, nutrition, and health. & {$[39,43]$} \\
\hline $\begin{array}{c}\text { NtN science (Nurture thru Nature): photosynthesis, animal migration, } \\
\text { natural selection, study of habitat and adaptation, health, and disease. }\end{array}$ & {$[46]$} \\
\hline Working with sensory experiences, health, and food. & {$[52,55]$} \\
\hline Working with sensor technology. & {$[53]$} \\
\hline Horticulture, health, nutrition, scientific environment, and leadership. & {$[41]$} \\
\hline
\end{tabular}

Similarly, as shown in Table 4, 28.57\% of the articles follow measurement contents, $19.05 \%$ geometric contents, $14.29 \%$ number blocks, and the same percentage work on statistics, randomness, and probability. Only $4.76 \%$ followed content on proportions, and fine and gross motor skills linked with mathematics. Article [38] covered mathematical concepts the most (measurement, numbers, geometry, and statistics and probability), followed by article [44] (measurement and numbers) and article [45] (geometry, probability and statistics).

Table 4. Curricular content of mathematics.

\begin{tabular}{cc}
\hline Curricular Content & Reference \\
\hline Unspecified & {$[11,40,42,49]$} \\
Addition, division, and logic through plants & {$[56]$} \\
Measurement & {$[38,44,47,51,53,55]$} \\
Numbers & {$[38,44,53]$} \\
Geometry & {$[38,45,50,55]$} \\
Statistics and probability & {$[38,45,47]$} \\
Proportions & {$[55]$} \\
Fine and gross motor skills & {$[44]$} \\
\hline
\end{tabular}

We certainly found that no studies aim to cover specific content, whether in the experimental sciences or mathematics, in the context of the school garden, in a structured or comprehensive way, by affirming that they use documents of the current rules and regulations of their state or country as a reference. As we already highlighted, the studies use contents from both subject areas, but only circumstantially; in other words, they adapt to the specific school garden experience that they wish to cover.

\subsection{Ages of the Participants}

The levels at which the proposals were followed are very disparate. For ease of approach to known standards of educational stages, we decided to form three groups according to the age of the participants. The first group was from three to six years. In this group, we found seven works $[11,39,43-46,56]$, of which only two $[43,44]$ carried out a full study at these ages. The rest included participants from the following group. The second group was from six to twelve years, in which there was no consensus on subdivisions of age in the entire section. For this reason, we decided not to divide this group. We found 18 studies in this age range [11,38-42,45-53,55-57]. Moreover, of those mentioned in the first group, only one [11] also belonged to the third group. Finally, we found only one study [11] in the third group, which was made up of participants aged over 12. 


\subsection{Project Duration}

Project duration was not specified in nine works. Where it was specified, only one study lasted for over a year, concretely for four years [52]. The other studies were for less than one year. One of them lasted for a school year [42] and another for seven months [57]. Three studies were held over six months [43,44,46], two over four months [53,54], and three studies lasted for three months $[39,45,56]$. This study [11] was a review of the literature spanning 20 years, from 1990 to 2010. Several studies provide great detail about dedication to the project, including the number of hours per week $[39,53]$. Others are less precise about duration, only indicating the seasons in which they were carried out [44,46]. Finally, the longest project [52] lasted for four years.

\subsection{Growing Food in the Garden and Use of Production}

Of all the studies analysed, only nine mention cultivating the garden $[11,39,43-45,49$, $50,52,55]$. No mention of this activity is made in the other studies. However, we believe it is fundamental. As for the use of the harvest, in cases where the garden was cultivated, we found two works that explain how it was used. In [49] the products were sold, while in [44] they were cooked to share with all programme participants, including families and community members. In the other studies in which the garden was cultivated, there is no specific mention of what was done with the production.

\subsection{Impact}

We understand impact to be the repercussions of garden-based learning in different areas. Table 5 reflects our understanding of the impact of the various studies. We observed a lack of homogeneity in general and in the improved areas, given that each project had different objectives.

Table 5. Improvements through the use of garden-based learning in schools.

\begin{tabular}{|c|c|c|}
\hline Major Category & Topic Specific Improvement & Reference \\
\hline \multirow{7}{*}{ General } & Improves academic performance & {$[41,57]$} \\
\hline & Pupils enjoy being outdoors & [57] \\
\hline & They feel more at ease physically & {$[57]$} \\
\hline & Improves creation and creativity & {$[40,53]$} \\
\hline & Improves critical thinking & {$[40]$} \\
\hline & Improves the social aspect & [51] \\
\hline & Improves garden use for studying another subject & [45] \\
\hline \multirow{6}{*}{$\begin{array}{l}\text { Attitudes towards the } \\
\text { experimental sciences }\end{array}$} & Improves attitudes towards nature/the environment & {$[48,50,54]$} \\
\hline & Improves learning in the sciences & {$[11,42,48,52]$} \\
\hline & Improves attitudes towards the sciences & [40] \\
\hline & Improves children's attitudes toward ecology in the school garden & [43] \\
\hline & Improves perceptions of nutrition through the school garden & [46] \\
\hline & Improves interest in gardening and horticulture & [39] \\
\hline \multirow{3}{*}{ Attitudes to mathematics } & Improves learning in mathematics & {$[11,47,50,52,56]$} \\
\hline & Improves attitudes to mathematics & {$[40,55]$} \\
\hline & Improves statistical literacy to improve scientific literacy & [49] \\
\hline STEM & Improves attitudes and learning & [51] \\
\hline
\end{tabular}

Study [42] explained that improvements take place in pupils aged eight to nine years and eleven to twelve years in horticulture, health, the environment, leadership, and nutrition. However, there was no improvement in mathematics. Furthermore, the authors of [42] observed that at age 11 years, this method should be combined with traditional classroom-based teaching. 


\section{Discussion}

The aim of this work was to discover and analyse studies on garden-based learning from the perspective of two specific subjects: the experimental sciences and mathematics, between the ages of three and twelve years, in Spain and other countries. To respond to this approach, we systematically reviewed documents published in three large databases: ERIC, Web of Science, and Scopus.

We can conclude that most of the experiences found were made in the USA. Of the 21 articles considered, 15 were studies from the USA $(71.44 \%)$, one was from Bangladesh $(4.76 \%)$, one was from Holland $(4.76 \%)$, two were from Greece $(9.52 \%)$, and two were unspecified $(9.52 \%)$. This result does not mean that there are no experiences in other places. Rather, in databases of internationally acknowledged scientific prestige, we only found studies carried out in the USA. This fact leads us to an important initial conclusion: the international scientific community undertaking garden-based experiences in schools is not distributing them for viewing in these channels. We would encourage the scientific community to do so because this is the ideal place for knowledge transfer. In accordance with the work of Desmond et al. [12], we believe that this lack of visibility could be because most publications relating to garden-based learning in schools are grounded in anecdotal evidence, with little associated empirical research. Hence, disseminating studies through these channels is complicated.

The studies found could arguably be divided into two groups: one is connected with narrations of experiences and the other encompasses research carried out on gardenbased learning experiences in schools. We found 15 publications of research studies: five presented a qualitative research method, six a quantitative research method and four followed a mixed methodology. As for the instruments used, we did find the same common tools: interviews and questionnaires. The latter were especially designed for specific educational intervention.

There was also considerable diversity in participants' age, if we consider that the age interval for our research was up to 12 years only. There were seven articles on children under six and one designed for pupils over 12 years but which began at younger ages. No experiences were limited to only one age. The duration of the studies was also varied but we can state that the experiences did not usually exceed half a school year: seven lasted more than half the academic year $(33.33 \%)$, six lasted half $(28.57 \%)$, and the duration of the rest was not specified $(38.10 \%)$.

The content followed also varied. In the experimental sciences, some studies focused on plants, while others concentrated more on animals, depending on the age of the participants. The case was similar for mathematics. The contents were highly varied, ranging from statistics to measurement, and the level of difficulty was adapted to the age of the participants. We found some articles that worked on specific mathematics contents in a natural garden context, some articles where only science contents were taught because mathematics was only a tool and a few articles where both science and mathematics curricular contents were shown but did not belong to the same educational level. In these cases, the mathematics content was always of a lower level. Therefore, both subjects were not connected for the same grade of primary education.

The impact of the studies we found, whether experiences or research studies, also varied considerably. Evidently, most attempt to improve attitudes and knowledge of the experimental sciences and even STEM. However, there were far fewer studies in mathematics and their impact varied significantly. We also found that some studies mention improvements in creativity and physical and even social progress. Each study responded to the specific objectives posited by the authors.

This great diversity makes us think that, if our objective was to have a fixed image of our three areas of interest: mathematics, the experimental sciences and garden-based learning, in an international and scientific sphere, the image we found is very much reduced. Indeed, we might say too reduced, which leads us to a second important conclusion. Once again, we invite the scientific community currently undertaking studies in garden-based 
learning to make an interdisciplinary use of curricular content and the experimental sciences in this context so that the variety of content we pinpointed in this review can be followed. There must, however, be a clear objective of the interdisciplinary contextualisation of mathematics and the experimental sciences in an area outside the conventional classroom, such as the school garden.

We understand that the future objective is far more ambitious because this joint study should be extended to other subjects, with a focus similar to the work of Desmond et al. [12], in which other subjects are incorporated, in addition to mathematics and the sciences. We believe it is interesting to rescue this interdisciplinary approach, as long as it is based on the curricular content of all the subjects, which are given equal importance.

Garden-based learning has an impact on numerous aspects such as respectful attitudes to the environment, to healthy nutrition, and to the sciences and mathematics, among others. We cannot establish a direct relationship between 'improves attitudes towards the sciences and/or mathematics' and 'improves academic performance' in these subjects, hence the need for publications in this line to confirm that this type of learning can bring about academic improvements in the subjects involved. We understand that to bring about these research studies, it would be appropriate to 'systematise' a way of working with the curricular content of the subjects involved to be able to replicate the results in any learning context where there is a garden. Although garden-based learning lacks a uniform pedagogical theory, because of the peculiarity of each place, we believe it would be possible to standardise the way of working with the curricular content of the various subjects for a specific school year. Although, maybe some theoretical and abstract mathematical contents should be reinforced in the classroom. One proposal is to design and apply sequences of teaching-learning that revolve around a series of teaching objectives with their corresponding activities, making it possible to work with the curricular content of each subject. These sequences could be structured over several phases, the final one being an assessment, to achieve results comparable to other works. We believe this could be a way of obtaining conclusive results for improving academic performance in the subjects studied.

Author Contributions: Conceptualization, L.M., G.L.-V. and M.S.-V.; methodology, L.M., G.L.-V. and M.S.-V.; formal analysis, L.M. and G.L.-V.; investigation, L.M. and M.S.-V.; resources, G.L.-V. and M.S.-V.; data curation, G.L.-V.; writing-original draft preparation, L.M., G.L.-V. and M.S.-V.; writing-review and editing, L.M., G.L.-V. and M.S.-V.; visualization, L.M. and M.S.-V.; supervision, L.M., G.L.-V. and M.S.-V. All authors have read and agreed to the published version of the manuscript.

Funding: This research was funded by University Jaume I, grant number 3966/21.

Institutional Review Board Statement: Not applicable.

Informed Consent Statement: Not applicable.

Data Availability Statement: Not applicable.

Conflicts of Interest: The authors declare no conflict of interest.

\section{References}

1. Hedley, A.A.; Ogden, C.L.; Johnson, C.L.; Carroll, M.D.; Curtin, L.R.; Flegal, K.M. Prevalence of overweight and obesity among US children, adolescents, and adults, 1999-2002. JAMA 2004, 291, 2847-2850. [CrossRef]

2. Harrison, K.; Bost, K.K.; McBride, B.A.; Donovan, S.M.; Grigsby-Toussaint, D.S.; Kim, J.; Liechty, J.M.; Wiley, A.; Teran-Garcia, M.; Jacobsohn, G.C. Toward a developmental conceptualization of contributors to overweight and obesity in childhood: The six-cs model: Developmental ecological model of child obesity. Child. Dev. Perspect. 2011, 5, 50-58. [CrossRef]

3. Serra Majem, L.; Ribas Barba, L.; Aranceta Bartrina, J.; Pérez Rodrigo, C.; Saavedra Santana, P.; Peña Quintana, L. Obesidad infantil y juvenil en España. Resultados del Estudio enKid (1998-2000). Med. Clin. 2003, 121, 725-732. [CrossRef]

4. Louv, R. Last Child in the Woods: Saving Our Children from Nature-Deficit Disorder; Algonquin Press: Chapel Hill, NC, USA, 2008.

5. Driessnack, M. Ask the expert. children and nature-deficit disorder. J. Spec. Pediatr. Nurs. 2009, 14, 73-75. [CrossRef]

6. Pollan, M. Second Nature: A Gardener's Education; Open Road+ Grove/Atlantic: New York, NY, USA, 2007.

7. Waters, A.; Duane, D. Edible Schoolyard; Chronicle Books: San Francisco, CA, USA, 2008.

8. Berezowitz, C.K.; Bontrager Yoder, A.B.; Schoeller, D.A. School gardens enhance academic performance and dietary outcomes in children. J. Sch. Health 2015, 85, 508-518. [CrossRef] 
9. Williams, D. Garden-Based Education; Oxford University Press: New York, NY, USA, 2018.

10. Sobel, D. Learning to walk between the raindrops: The value of nature preschools and forest kindergartens. Child. Youth Environ. 2014, 24, 228. [CrossRef]

11. Williams, D.R.; Dixon, P.S. Impact of garden-based learning on academic outcomes in schools: Synthesis of research between 1990 and 2010. Rev. Educ. Res. 2013, 83, 211-235. [CrossRef]

12. Desmond, D.; Grieshop, J.; Subramaniam, A. Revisiting Garden-Based Learning in Basic Education; Food and Agriculture Organization of the United Nations: Rome, Italy, 2004.

13. Eugenio Gozalbo, M.; Ramos Truchero, G.; Vallés Rapp, C. Huertos Universitarios: Dimensiones de aprendizaje percibidas por los futuros maestros. Enseñanza Cienc. 2019, 37, 111-127.

14. Dewey, J. Experience and Education; Palgrave MacMillan: New York, NY, USA, 1938.

15. Kolb, D.A. Experiential Learning. Experience as the Source of Learning and Development; Prentice-Hall: Englewood Cliffs, NJ, USA, 1984

16. Smith, T.E.; Knapp, C.E. (Eds.) Sourcebook of Experiential Education: Key Thinkers and Their Contributions; Routledge: New York, NY, USA, 2011.

17. Stevenson, R.P.; Brody, M.; Dillon, J.; Wals, A.E. International Handbook of Research on Environmental Education; Routledge: New York, NY, USA, 2014. [CrossRef]

18. Flake, C. Holistic Education: Principles, Practices, and Perspectives; Holistic Education Press: Brandon, VT, USA, 2001.

19. Miller, R. (Ed.) The Renewal of Meaning in Education: Responses to the Cultural and Ecological Crisis of Our Times; Holistic Education Press: Brandon, VT, USA, 1993.

20. Potter, T.G.; Dyment, J.E. Is outdoor education a discipline? Insights, gaps and future directions. J. Adventure Educ. Outdoor Learn. 2016, 16, 146-159. [CrossRef]

21. Rickinson, M.; Dillon, J.; Teamey, K.; Morris, M.; Choi, M.; Sanders, D.; Banefiled, P. A Review of Research on Outdoor Learning; National Foundation for Educational Research and King's College: London, UK, 2003.

22. Wattchow, B.; Brown, M. A Pedagogy of Place: Outdoor Education for a Changing World; Monash University Publishing: Clayton, Australia, 2011.

23. Gruenewald, D.A.; Smith, G.A. (Eds.) Place-Based Education in the Global Age: Local Diversity; Routledge: London, UK, 2008.

24. Smith, G.A.; Sobel, D. Place- and Community-Based Education in Schools; Routledge: New York, NY, USA, 2010.

25. Williams, D.; Brown, J. Learning Gardens and Sustainability Education: Bringing Life to Schools and Schools to Life; Routledge: New York, NY, USA, 2013.

26. Thompson, S.; Corkery, L.; Judd, B. The Role of community gardens in sustaining healthy communities. In Proceedings of the Third State of Australian Cities Conference, Adelaide, Australia, 28-30 November 2007.

27. Braund, M.; Reiss, M. Towards a more authentic science curriculum: The contribution of out-of-school learning. Int. J. Sci. Educ. 2006, 28, 1373-1388. [CrossRef]

28. Fägerstam, E. High school teachers' experience of the educational potential of outdoor teaching and learning. J. Adventure Educ. Outdoor Learn. 2014, 14, 56-81. [CrossRef]

29. Uitto, A.; Juuti, K.; Lavonen, J.; Meisalo, V. Student's interest in biology and their out-of-school experiences. J. Biol. Educ. 2006, 40, 124-129. [CrossRef]

30. Dubiel, M. Math trail in Beacon Hill Park. In Proceedings of the Northwest Mathematics Conference, Victoria, BC, Canada, 15 October 2000.

31. Braund, M.; Reiss, M. Validity and worth in the science curriculum: Learning school science outside the laboratory. Curric. J. 2006 17, 213-228. [CrossRef]

32. Bogner, F.X. The influence of a residential outdoor education programme to pupil's environmental perception. Eur. J. Psychol. Educ. 2002, 17, 19-34. [CrossRef]

33. Fägerstam, E.; Blom, J. Learning biology and mathematics outdoors: Effects and attitudes in a swedish high school context. J. Adventure Educ. Outdoor Learn. 2013, 13, 56-75. [CrossRef]

34. Fägerstam, E.; Grothérus, A. Secondary school students'experience of outdoor learning: A swedish case study. Education 2018, $138,378-392$.

35. Motta, R. Complejidad, educación y transdisciplinariedad. Polis. Rev. Latinoam. 2002, 3.

36. De Guzmán, M. Enseñanza de las ciencias y la matemática. Rev. Iberoam. De Educ. 2007, 43, 19-58.

37. 37. Moher, D.; Liberati, A.; Tetzlaff, J.; Altman, D.G.; PRISMA Group. Preferred reporting items for systematic reviews and meta-analyses: The PRISMA statement. BMJ 2009, 339, b2535. [CrossRef]

38. Hinnant, H.A. Growing gardens and mathematicians: More books and math for young children. Young Child. 1999, 54, 23-26.

39. Meyer, M.H.; Hegland, N.N.; Fairbourne, P. Junior master gardener programs in Minnesota. Horttechnology 2001, 11, 665-667. [CrossRef]

40. Waliczek, T.M.; Logan, P.; Zajicek, J.M. Exploring the impact of outdoor environmental activities on children using a qualitative text data analysis system. Horttechnology 2003, 13, 684-688. [CrossRef]

41. Klemmer, C.D.; Waliczek, T.M.; Zajicek, J.M. Development of a science achievement evaluation instrument for a school garden program. Horttechnology 2005, 15, 433-438. [CrossRef] 
42. Pigg, A.E.; Waliczek, T.M.; Zajicek, J.M. Effects of a gardening program on the academic progress of third, fourth, and fifth grade math and science students. Horttechnology 2006, 16, 262-264. [CrossRef]

43. Miller, D.L. The seeds of learning: Young children develop important skills through their gardening activities at a midwestern early education program. Appl. Environ. Educ. Commun. 2007, 6, 49-66. [CrossRef]

44. Starbuck, S.; Olthof, M.R. Involving families and community through gardening. YC Young Child. 2008, 63, 74.

45. Boynton, C.M. Learning Spaces in School: Comparing Math Instruction and Learning in School Gardens and Classrooms. Ph.D. Thesis, University of California, Berkeley, CA, USA, 2010.

46. Jaeschke, E.M.; Schumacher, J.R.; Cullen, R.W.; Wilson, M.A. Perceptions of principals, teachers, and school food, health, and nutrition professionals regarding the sustainability and utilization of school food gardens. J. Child. Nutr. Manag. 2012, $36,7-13$.

47. Taylor, E.V. Supporting children's mathematical understanding: Professional development focused on out-of-school practices. $J$. Math. Teach. Educ. 2012, 15, 271-291. [CrossRef]

48. Fisher-Maltese, B.C. Fostering Science Literacy, Environmental Stewardship, and Collaboration: Assessing a Garden-Based Approach to Teaching Life Science. Ph.D. Thesis, Rutgers, The State University of New Jersey, New Brunswick, NJ, USA, 2013.

49. Selmer, S.J.; Rye, J.A.; Malone, E.; Fernandez, D.; Trebino, K. What should we grow in our school garden to sell at the farmer's market? Initiating statistical literacy through science andmathematics integration. Sci. Act. 2014, 51, 17-32. [CrossRef]

50. Akoumianaki-Ioannidou, A.; Chatzaki, M.; Koutsouris, A. Fostering the educational role of plants through the development of an alternative teaching aid for maths. Acta Hortic. 2017, 1189, 49-52. [CrossRef]

51. Brkich, K.; Allen, M.; Huffling, L.; Matthews, C. Toad-Ally cool: Math and science integration: A summer science camp for girls teaches about herpetology while encouraging interest in science, technology, engineering, and mathematics STEM. Math Child. 2017, 54, 30.

52. Camasso, M.J.; Jagannathan, R. Improving academic outcomes in poor urban schools through nature-based learning. Camb. J. Educ. 2018, 48, 263-277. [CrossRef]

53. Davis, T. Engineering encounters: The internet of things for kids. Sci. Child. 2017, 54, 84. [CrossRef]

54. Ürey, M.; Göksu, V.; Ataman Karaçöp, Y. Teacher's views about school garden program developed for free activities course Serbest Etkinlik Çalışmaları Dersi Kapsamında Geliştirilen Okul Bahçesi Programına Yönelik Öğretmen Görüşleri. Elem. Educ. Online 2017, 16, 1-14.

55. Jagger, S. Opening a space of/for curriculum: The learning garden as context and content for difference in mathematics education. In Transdisciplinarity in Mathematics Education; Springer International Publishing: Cham, Switzerland, 2018; pp. 89-106.

56. Savi, A.O.; Ruijs, N.M.; Maris GK, J.; van der Maas, H.L.J. Delaying access to a problem-skipping option increases effortful practice: Application of an a/b test in large-scale online learning. Comput. Educ. 2018, 119, 84-94. [CrossRef]

57. Khan, M.; McGeown, S.; Bell, S. Can an outdoor learning environment improve children's academic attainment? A quasiexperimental mixed methods study in bangladesh. Environ. Behav. 2020, 52, 1079-1104. [CrossRef] 